\title{
Complex of Platinum(II) with Tris(2-carboxyethyl)phosphine Induces Apoptosis in Canine Lymphoma/Leukemia Cell Lines
}

\author{
MARTA HENKLEWSKA ${ }^{1}$, ALEKSANDRA PAWLAK ${ }^{1}$, \\ HANNA PRUCHNIK $^{2}$ and BOZENA OBMINSKA-MRUKOWICZ ${ }^{1}$ \\ ${ }^{1}$ Department of Biochemistry, Pharmacology and Toxicology, \\ Wroclaw University of Environmental and Life Sciences, Wroclaw, Poland; \\ ${ }^{2}$ Department of Physics and Biophysics, Faculty of Life Sciences and Technology, \\ Wroclaw University of Environmental and Life Sciences, Wroclaw, Poland
}

\begin{abstract}
Background/Aim: Platinum-based drugs are a very potent class of anticancer drugs commonly used in anticancer therapy. However, resistance development and severe adverse effects make further research on new platinum derivatives necessary. In this study, cytotoxic activity of a new platinum(II) compound containing tris(2-carboxyethyl)phosphine (TCEP) ligand cis-[PtCl $\left.\mathrm{PTCEP}_{2}\right]$ was tested against canine lymphoma and leukemia cell lines and its activity was compared to that of cisplatin. Materials and Methods: Cells were exposed for $24 \mathrm{~h}$ to increasing concentrations of the studied compounds and cell viability was assessed by propidium iodide staining. Disturbances in apoptosis rate and cell cycle were also examined. Results: Cytotoxic activity of the new platinum complex cis-[PtCl $\left.{ }_{2}(\mathrm{TCEP})_{2}\right]$ was higher compared to that of cisplatin and cell death was associated with apoptosis. However, the tested compound differently affected the cell-cycle progression than cisplatin. Conclusion: The cis- $\left[\mathrm{PtCl}_{2}(\mathrm{TCEP})_{2}\right]$ seems to be a potent anticancer agent, although further investigations are necessary to elucidate its biological activity.
\end{abstract}

Platinum-based drugs constitute a very active class of anticancer agents broadly used in human medicine against a wide spectrum of cancers (1). The first such a drug introduced into medicine was cisplatin (cis- $\left[\mathrm{PtCl}_{2}\left(\mathrm{NH}_{3}\right)_{2}\right]$ cis-diamminedicholoroplatinum CDDP), approved by Food and Drug Administration in 1978 (2). In human medicine,

Correspondence to: Marta Henklewska, Department of Biochemistry, Pharmacology and Toxicology, Faculty of Veterinary Medicine, Wroclaw University of Environmental and Life Sciences, Norwida 31, 50-375 Wroclaw, Poland. Tel: +48 713205403, Fax: +48 713205455, e-mail: marta.henklewska@up.wroc.pl

Key Words: Pt-TCEP, cisplatin, canine lymphoma, canine leukemia, apoptosis. cisplatin is used against ovarian, testicular, bladder, colorectal, small-cell lung, esophageal, cervical, head and neck cancers, lymphomas, melanomas, and many others (1, $3,4)$. Cisplatin has been also introduced in veterinary medicine, where it is used in systemic or local chemotherapy, as a single agent or as a part of a combination therapy (5). Its usefulness in treatment of canine osteosarcoma as an adjuvant therapy to amputation was strongly confirmed, and cisplatin was proved to significantly prolong survival time after surgery (6-9). Cisplatin is also used as a radio-sensitizer in dogs (10) and in intralesional therapy of cutaneous tumors such as squamous cell papillomas (SCC) and sarcoids in horses $(11,12)$. Nevertheless, cisplatin usage is limited by inherent or acquired resistance and strong toxicity including nephrotoxicity, peripheral neuropathy, ototoxicity, nausea and vomiting $(13,14)$.

Many efforts have been made to develop new analogs of cisplatin with other mechanisms of action and with activity against cancers resistant to cisplatin $(2,15)$. Advances in understanding the mechanism of action and resistance to cisplatin enabled a design of more efficient platinum-based drugs to benefit cancer patients (2). To date, two such drugs have gained worldwide approval: carboplatin with similar to cisplatin mode of action and oxaliplatin that forms adducts with DNA strand different than both, cisplatin and carboplatin and thus has a different spectrum of activity $(1,2,4)$. Nevertheless, it is still necessary to develop new platinumbased drugs that show other modes of action and activate different pathways leading to an induction of apoptosis. This effort seems to be worth making due to high anticancer potential of this class of drugs and the resistance and strong side-effects of existing platinum-based agents. Recently, a new platinum-based compounds containing a phosphine ligand tris(2-carboxyethyl)phosphine $\left[\mathrm{P}\left(\mathrm{CH}_{2} \mathrm{CH}_{2} \mathrm{COOH}\right)_{3}\right]$ (TCEP) instead of ammonia group and two chlorine atoms in cis and in trans conformation with potential anticancer activity has been introduced (16). TCEP is a fast and strong 
sulphhydryl reducing agent cleaving disulfide linkage in proteins, peptides and other compounds containing S-S bond $(16,17)$. Since 1991, when a direct and convenient method of TCEP synthesis was manufactured (17), it has been commercially available and widely used in biochemistry as a reducing agent to mimic natural, reducing environment, so that sulphhydryl groups of proteins, including enzymes, could remain in their reduced form and preserve their activity in solutions (18). It was also observed that TCEP can reduce disulfide bonds between cysteine residues in proteins and peptides and subsequently cleave cysteine-containing proteins (19). TCEP is often used as a reducing agent in the study of interactions of proteins with metal complexes (16) and recently it has been discovered that it promotes the reaction of cisplatin with zinc finger protein Sp1 (20). Specificity protein $(\mathrm{Sp})$ family is a large family of transcription factors belonging to zinc finger proteins, that may regulate an expression of multiple genes involved in the cell cycle, proliferation, differentiation, apoptosis and tumorigenesis (21). Specifically, over-expression of Sp proteins, including $\mathrm{Sp} 1$, is involved in cancer development and hence may be used as targets for cancer chemotherapy $(21,22)$.

The aim of the study was to compare the anticancer effect of platinum(II) complex with tris(2-carboxyethyl)phosphine, cis- $\left[\mathrm{PtCl}_{2}(\mathrm{TCEP})_{2}\right]$ (Pt-TCEP) and cisplatin on canine lymphoma (CLBL-1, CL-1) and leukemia (GL-1) cell lines.

\section{Materials and Methods}

Cell lines and culture. Different canine lymphoma/leukemia cell lines CLBL-1 (B-cell lymphoma cell line), GL-1 (B-cell leukemia) and CL-1 (T-cell lymphoma) were used in this study. CLBL-1 cells were obtained from Barbara C. Ruetgen, Department of Pathobiology, Institute of Immunology, at the University of Veterinary Medicine in Vienna (23) and GL-1 and CL-1 were obtained from Yasuhito Fujino and Hajime Tsujimoto, respectively, from the Department of Veterinary Internal Medicine at the University of Tokyo $(24,25)$. CLBL-1, GL-1 and CL-1 cell lines were maintained in RPMI 1640 culture medium supplemented with $2 \mathrm{mM} \mathrm{L}$-glutamine, $100 \mathrm{U} / \mathrm{mL}$ penicillin and $100 \mu \mathrm{g} / \mathrm{mL}$ streptomycin and $10 \%$ heat-inactivated fetal bovine serum (FBS). The culture was maintained in the atmosphere of $5 \% \mathrm{CO}_{2}$ and $95 \%$ humidified air at $37^{\circ} \mathrm{C}$. The cells were cultured in $75 \mathrm{~cm}^{2}$ cell culture flasks (Corning, USA) and subcultivated every other day to keep at optimal density (i.e. $60-70 \%$ of confluence).

Chemicals and reagents. The (cis- $\left.\left[\mathrm{PtCl}_{2}(\mathrm{TCEP})_{2}\right]\right)$ was prepared by procedures reported earlier (16). TCEP $\left[\mathrm{P}\left(\mathrm{CH}_{2} \mathrm{CH}_{2} \mathrm{COOH}\right)_{3}\right]$, CDDP (cis-[ $\left.\left.\mathrm{PtCl}_{2}\left(\mathrm{NH}_{3}\right)_{2}\right]\right)$, fetal bovine serum (FBS), L-glutamine, penicillin and streptomycin solution, ribonuclease $\mathrm{A}$ and propidium iodide were purchased from Sigma-Aldrich (Steinheim, Germany). Dimethyl sulphoxide (DMSO) and ethanol were acquired from POCh (Gliwice, Poland). Annexin V FITC was bought from Immunostep (Salamanca, Spain). Phosphate buffered saline (PBS) and RPMI 1640 culture medium were obtained from the Institute of Immunology and Experimental Therapy (Wroclaw, Poland).
Drug preparation. Pt-TCEP and TCEP were dissolved in DMSO to prepare $5 \mathrm{mM}$ stock solutions and CDDP was dissolved in $0.9 \%$ sterile saline to prepare $2.5 \mathrm{mM}$ stock solution. The stock solutions were stored at $-20^{\circ} \mathrm{C}$ until they were added to the culture medium to obtain target experimental solutions.

Determination of cell viability. To evaluate and compare the effects exerted by Pt-TCEP and CDDP on the cultures of canine lymphoma (CLBL-1, CL-1) and leukemia (GL-1) cell lines, cells were treated with increasing concentrations of Pt-TCEP $(0.078,0.156,0.3125$, $0.625,1.25,2.5$, and $5 \mu \mathrm{M})$ and $\operatorname{CDDP}(0.625,1.25,2.5,5,10,20$, and $40 \mu \mathrm{M}$ ) for $24 \mathrm{~h}$. Additionally, TCEP alone, as a substrate used in the synthesis of the studied compound, was examined at the concentrations similar to those of Pt-TCEP. The cells were seeded in concentration of $1 \times 10^{4}$ cells per well in a 96-well-plate (TPP, Trasadingen, Switzerland). The compounds were prepared at indicated dilutions in the culture medium (DMSO concentration was less than $0.1 \%$ in each dilution, which is considered harmless to the cells) and added to the plates with cells. The cells were incubated in the medium alone or in the medium containing either the vehicle control or increasing concentration of the tested substance for $24 \mathrm{~h}$. After the incubation, the cells were harvested and washed twice in PBS, transferred into cytometric tubes and stained with propidium iodide (PI, final concentration $1 \mu \mathrm{g} / \mathrm{mL}$ ). Flow cytometry analysis was performed immediately after, using the flow cytometer FACS Calibur (Becton Dickinson, Biosciences, San Jose, USA). CellQuest 3.lf. software (Becton Dickinson, San Jose, USA) was used for data analysis on the basis of histograms of FL2-H showing the population of live (PI negative) and dead (PI positive) cells. The values presented as means with standard deviation were obtained from three independent experiments and showed as a concentrationdepended curve. $\mathrm{IC}_{50}$ for Pt-TCEP and CDDP was calculated as a mean concentration inhibiting cell viability by $50 \%$ in three independent experiments.

Apoptosis analysis. At the next stage we checked whether the inhibition of cell viability was associated with apoptosis. For this purpose, flow cytometry analysis of Annexin- $\mathrm{V}$ binding to phosphatidylserine residues was performed. For comparison of the apoptosis rate after $24 \mathrm{~h}$ exposure to Pt-TCEP in three studied cell lines, the concentration of $1 \mu \mathrm{M}$ was chosen based on the results of cell viability assay. Additionally, the cells of three canine cancer cell lines were treated with $15 \mu \mathrm{M}$ of CDDP. Apoptotic events were detected using Annexin V-FITC/PI staining. Briefly, the cells were treated with the tested compounds at the indicated concentrations for $24 \mathrm{~h}$. After harvesting, the cells were washed twice with cold PBS, suspended in a binding buffer and stained with Annexin VFITC for $10 \mathrm{~min}$ at room temperature. After the incubation, propidium iodide (PI) was added and flow cytometric analysis was immediately performed using a flow cytometer (FACS Calibur; Becton Dickinson, Biosciences, San Jose, USA). CellQuest 3.lf. software (Becton Dickinson, San Jose, USA) was used for data analysis.

Cell-cycle analysis. GL-1 cell line that appeared to be moderately sensitive to Pt-TCEP in cell viability assay was used for cell cycle analysis. Briefly, GL-1 cells were seeded in 24-well plates (TPP, Trasadingen, Switzerland) for $24 \mathrm{~h}$ with the tested compounds at a concentration of $1 \mu \mathrm{M}$ (Pt-TCEP) and $15 \mu \mathrm{M}$ (CDDP). After incubation, the cells were harvested and washed twice in PBS. 
Then, they were fixed in cold $70 \%$ ethanol and incubated for at least one hour at $4^{\circ} \mathrm{C}$. After the second cycle of washing, the cells were treated with ribonuclease (final RNAse concentration $0.5 \mathrm{mg} / \mathrm{mL}$ ), incubated for $1 \mathrm{~h}$ and stained with propidium iodide (PI) (final concentration $10 \mu \mathrm{g} / \mathrm{mL}$ ). The sample analysis was performed using a flow cytometer (FACS Calibur; Becton Dickinson, Biosciences, San Jose, CA) and CellQuest 3.lf. software. Based on FL-2H histograms, percentage of the cells in sub-G0, $\mathrm{G}_{0} / \mathrm{G}_{1}, \mathrm{~S}$ and $\mathrm{G}_{2} / \mathrm{M}$ phase was compared with the results for untreated controls. The presented results were obtained from three independent experiments.

Statistical analysis. All data were shown as means with standard deviations (SD). Statistical difference was analyzed using Student's $t$-test for normally distributed values and one-way ANOVA followed by Tukey's post hoc test was used to test statistical differences among treatment groups. The results were considered significant when $p<0.05$.

\section{Results}

Determination of cell viability. The study demonstrated that incubation with Pt-TCEP for $24 \mathrm{~h}$ induced cell death in canine cancer cell lines in a concentration-depended manner (Figure 1). The efficacy of the new compound was much higher than that of CDDP $(p<0.05)$. Furthermore, in CLBL1 and GL- 1 cell lines treated with $2.5 \mu \mathrm{M}$ Pt-TCEP nearly $100 \%$ of the cells were killed (cell viability at this concentration was $5.33 \pm 2.21 \%$ and $1.68 \pm 0.47 \%$ for GL- 1 and CLBL-1 cell line, respectively), while viability of the cells exposed to cisplatin at this concentration was not statistically different from the control $(p>0.05)$. Viability of CL-1 cell line at the highest concentration of Pt-TCEP $(5 \mu \mathrm{M})$ was reduced to $26.50 \pm 6.1 \%$ and at the same concentration of CDDP it was reduced to $79.70 \pm 1.32 \%$. TCEP alone did not exhibit any cytotoxic activity at the concentrations analogous to those of Pt-TCEP.

The $\mathrm{IC}_{50}$ for Pt-TCEP after $24 \mathrm{~h}$ treatment is shown in Figure 2. CLBL-1 line was the most sensitive to Pt-TCEP with $\mathrm{IC}_{50}$ of $0.92 \pm 0.05 \mu \mathrm{M}$, while $\mathrm{CL}-1$ cell line was the most resistant and its viability was inhibited by $50 \%$ at Pt-TCEP concentration of $2.59 \pm 0.03 \mu \mathrm{M}(p<0.05) . \mathrm{IC}_{50}$ for Pt-TCEP in GL-1 cell line was determined at $1.35 \pm 0.07 \mu \mathrm{M}$. $\mathrm{IC}_{50}$ of CDDP was also calculated and it was $25.98 \pm 3.74 \mu \mathrm{M}$ and $22.99 \pm 2.42 \mu \mathrm{M}$ for GL-1 and CLBL-1 cell line, respectively. As shown in Figure 3, viability of CL-1 cell line treated with $10 \mu \mathrm{M}$ CDDP decreased to $67.13 \pm 1.58 \%$ but at higher CDDP concentrations it increased to over $70 \%$ and finally $\mathrm{IC}_{50}$ was not achieved at the highest concentration studied $(40 \mu \mathrm{M})$. Moreover, cell viability assay showed that although at 5 and $10 \mu \mathrm{M}$ CDDP the sensitivity of CL- 1 cell line was higher than that of the other two cell lines, at higher CDDP concentrations the sensitivity of CL-1 cell line decreased and at the highest concentration studied $(40 \mu \mathrm{M})$ it was lower than in GL-1 and CLBL-1 cell lines $(p<0.05)$.

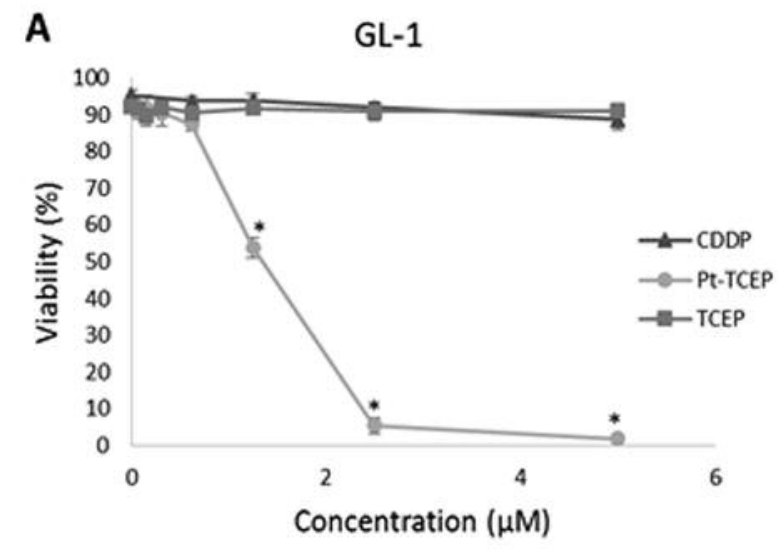

B
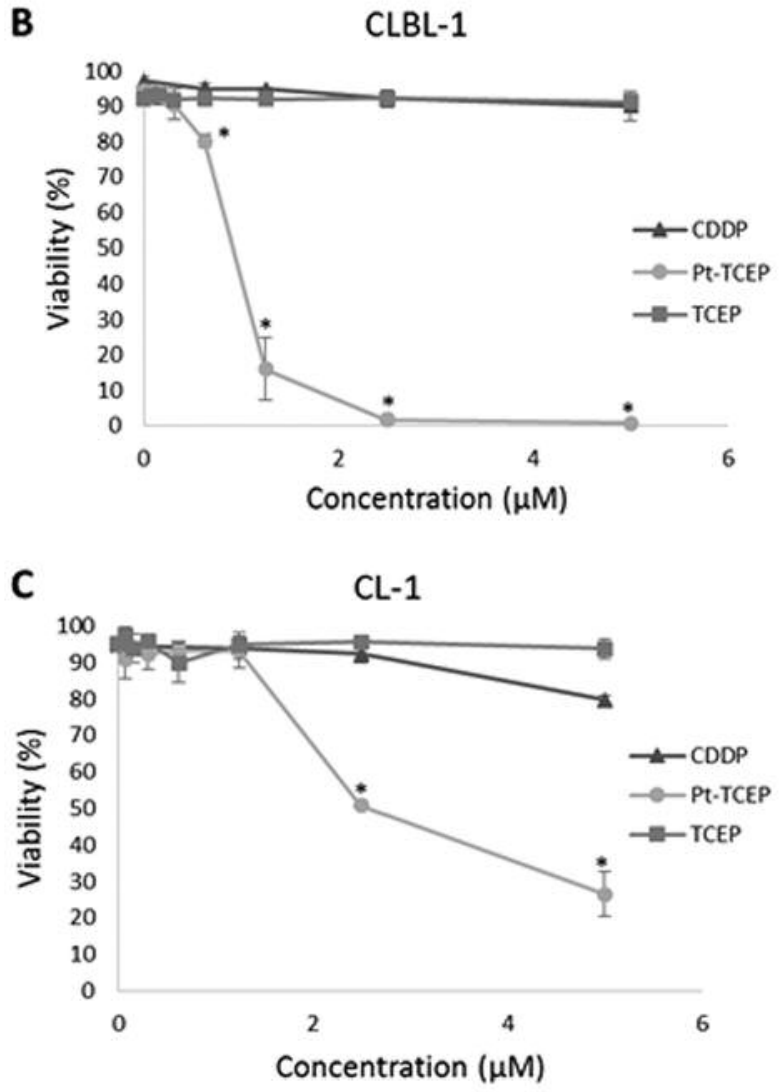

Figure 1. Comparison of the effect of increasing concentration $(\mu M)$ of CDDP, Pt-TCEP and TCEP alone on cell viability (PI staining) in three canine cell lines: $G L-1$ (A), CLBL-1 (B) and CL-1 (C) after $24 \mathrm{~h}$ incubation. Values are expressed as means $\pm S D$ of three independent experiments. Asterisk indicates statistical significance compared to control $(p<0.05)$.

Apoptosis analysis. The percentage of apoptotic cells after $24 \mathrm{~h}$ treatment with $1 \mu \mathrm{M}$ Pt-TCEP increased to $31.25 \pm 1.16 \%, 65.53 \pm 2.89 \%$ and $12.35 \pm 0.44 \%$ for GL-1, CLBL- 1 and CL-1 cell line, respectively $(p<0.05)$ (Figure $4)$. CDDP at $15 \mu \mathrm{M}$ enhanced the percentage of apoptotic 


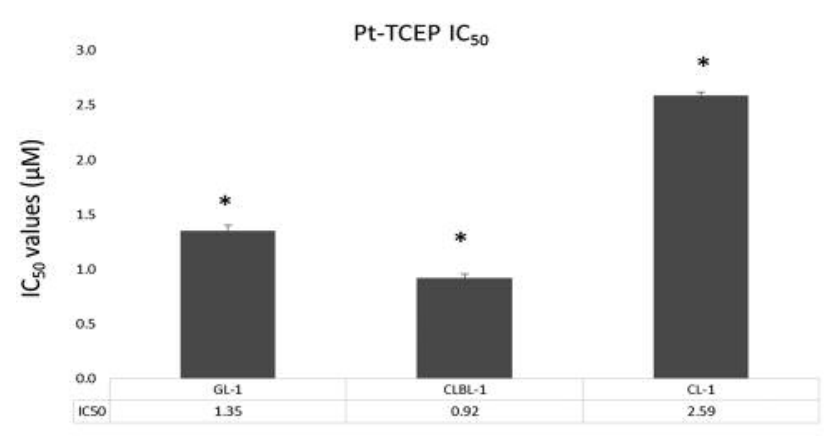

Figure 2. Mean $( \pm S D) I C_{50}(\mu M)$ for Pt-TCEP in three canine cancer cell lines after 24 h exposure. Values were calculated as means $\pm S D$ of three independent experiments (PI staining). Asterisk indicates statistical significance compared to control $(p<0.05)$.

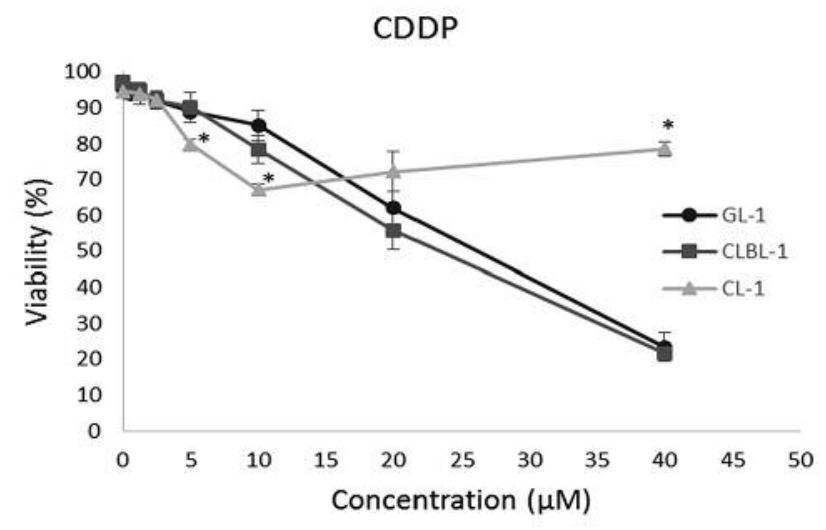

Figure 3. Comparison of cell viability (PI staining) in three canine cell lines: $G L-1, C L B L-1$ and $C L-1$ after $24 \mathrm{~h}$ incubation with increasing concentration $(\mu M)$ of $C D D P$. Values are expressed as means $\pm S D$ of three independent experiments. Asterisk indicates statistical significance compared to control $(p<0.05)$.

cells to $37.80 \pm 3.9 \%, 45.67 \pm 5.58 \%$ and $37.80 \pm 5.76 \%$ for GL-1, CLBL-1 and CL- 1 cell lines, respectively $(p<0.05)$. This indicated that the apoptosis rate following the exposure to $15 \mu \mathrm{M}$ CDDP was similar in all cell lines investigated in the study $(p>0.05)$. However, taking into account the results of cell viability assay (Figure 3), it was also examined whether the percentage of apoptotic cells in CL-1 cell line increased at higher concentrations of CDDP. It turned out that the percentage of apoptotic cells did not increase in a concentration-depended manner and at $40 \mu \mathrm{M}$ of CDDP was the same as at $15 \mu \mathrm{M}(p>0.05)$, reflecting the results of the viability assay (data not shown). Representative dot plots of Annexin V-FITC/PI staining of GL-1, CLBL-1 and CL-1 cell lines after incubation with $1 \mu \mathrm{M}$ Pt-TCEP and $15 \mu \mathrm{M}$ CDDP are shown in Figure 5.

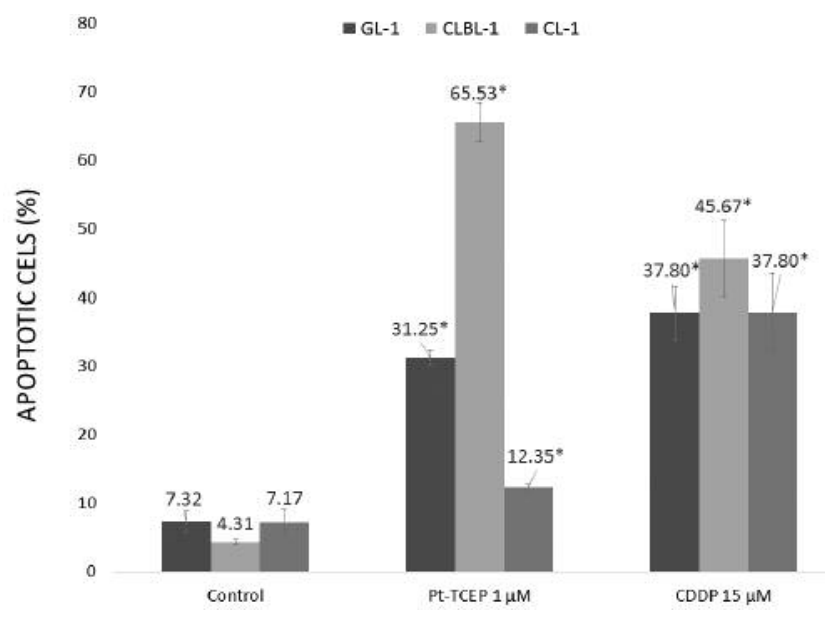

Figure 4. Percentage of apoptotic cells $(\%)$ in three canine cancer cell lines GL-1, CLBL-1, CL-1 after 24 h exposure to $1 \mu \mathrm{M}$ of Pt-TCEP and $15 \mu M$ of $C D D P$. Values are expressed as means $\pm S D$ of three independent experiments (Annexin V-FITC/PI staining). Asterisk indicates statistical significance compared to control $(p<0.05)$.

Cell-cycle analysis. Incubation with $1 \mu \mathrm{M}$ of Pt-TCEP increased the percentage of cells in sub- $\mathrm{G}_{0}$ phase from $2.96 \pm 0.75 \%$ in control to $31.50 \pm 5.73 \%$ and decreased the percentage of cells in $\mathrm{G}_{0} / \mathrm{G}_{1}$ phase from $65.03 \pm 2.36 \%$ in control to $53.20 \pm 3.08 \%$, in $S$ phase from $14.95 \pm 1.59 \%$ in control to $8.11 \pm 1.99 \%$, and in $\mathrm{G}_{2} / \mathrm{M}$ phase from $17.03 \pm 1.99 \%$ in control to $7.21 \pm 1.38 \%(p<0.05)$ (Figure 6). In CDDP variant, the increase in the percentage of cells in sub- $\mathrm{G}_{0}$ reached $48.27 \pm 5.66 \%$ after the incubation with $15 \mu \mathrm{M}$ CDDP, as compared with $2.96 \pm 0.75 \%$ in control. CDDP decreased the amount of cells in the $\mathrm{G}_{0} / \mathrm{G}_{1}$ phase from $65.03 \pm 2.36 \%$ in control to $25 \pm 2.54 \%$ and the cells in $\mathrm{G}_{2} / \mathrm{M}$ phase from $17.03 \pm 1.99 \%$ in control to $7.67 \pm 0.46 \%(p<0.05)$. Contrary to Pt-TCEP, the decrease in amount of cells in $\mathrm{S}$ phase was not observed and was calculated to be $19 \pm 3.05 \%(p>0.05)$.

\section{Discussion}

Due to high activity of platinum-based compounds, research on new derivatives with intensified cytotoxic activity to enhance the antineoplastic efficacy of platinum drugs are constantly being undertaken. Many new analogs of cisplatin have been designed and tested. Some of them were successful in clinical trials and were introduced in medical practice. Other are still under scrutiny $(1,4,26)$. Platinum complexes with phosphine derivatives were also investigated for their anticancer properties and some of them exhibited higher cytotoxic activity than cisplatin. They were also active against cancer cell lines resistant to 

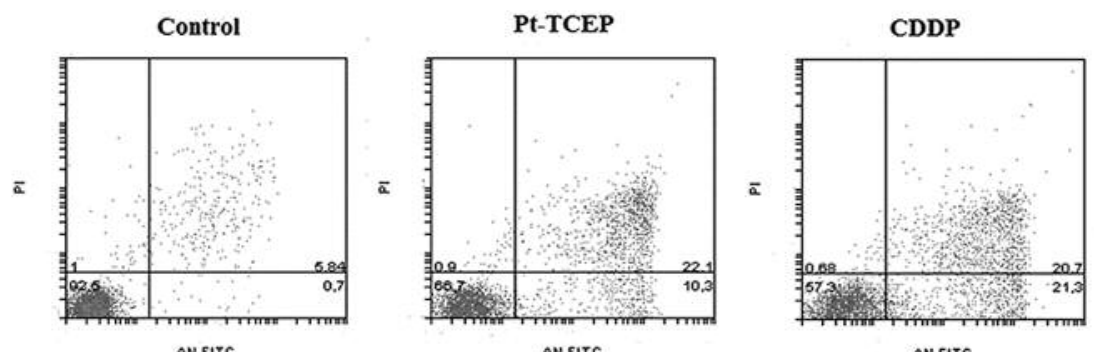

$\mathbf{A}$
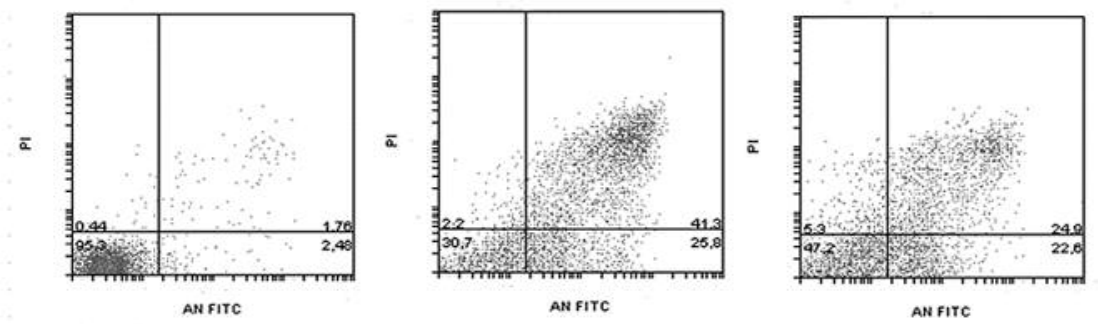

B
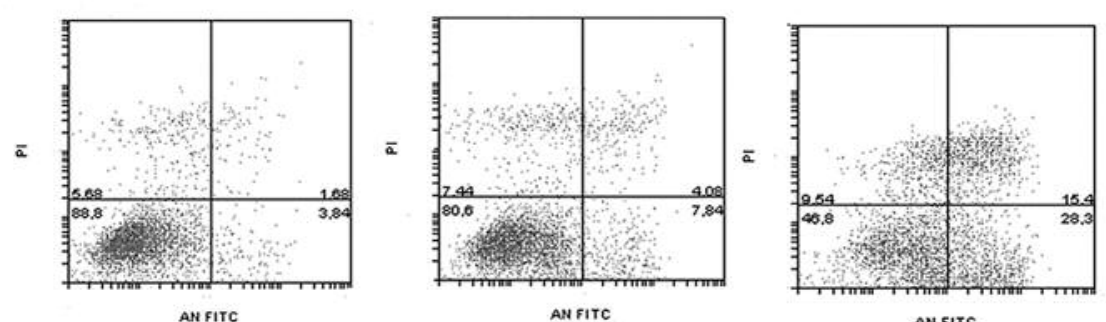

C

Figure 5. Representative dot plots showing Annexin V-FITC/PI staining of GL-1,CLBL-1, and CL-1 after 24 h incubation with $1 \mu M$ Pt-TCEP and $15 \mu M C D D P$.

cisplatin (27-31). Phosphine ligands combined with other metals such as gold or palladium also showed a cytotoxic potential (32-35).

The study clearly indicated that Pt-TCEP was more potent in inducing cell death than CDDP in all three canine cancer cell lines. As shown in cell viability assay, Pt-TCEP reduced cell viability at lower concentrations than CDDP. Additionally, CDDP was not able to reduce cell viability in concentrations similar to those, which indicated cell viability inhibition in the case of Pt-TCEP. CLBL-1 cell line was the most sensitive and CL-1 the most resistant to Pt-TCEP. These results are similar to the results of previous studies, in which CL- 1 cell line was the most resistant and CLBL- 1 the most sensitive to various anticancer drugs such as cytosine arabinose, chlorambucil, 4-HO-cyclophosphamide, etoposide, and vincristine (36). The results for CDDP were not that obvious. There was no significant difference in the sensitivity of GL-1 and CLBL-1 cell line, while cell viability of CL-1 cell line decreased to $67.13 \pm 1.58 \%$ at $10 \mu \mathrm{M}$ CDDP but increased to over $70 \%$ at higher concentrations. However, PtTCEP at $5 \mu \mathrm{M}$ was capable of decreasing cell viability in this cell line to $26.50 \pm 6.1 \%$, while for CDDP at this concentration the cell viability decreased only to $79.70 \pm 1.32 \%$.

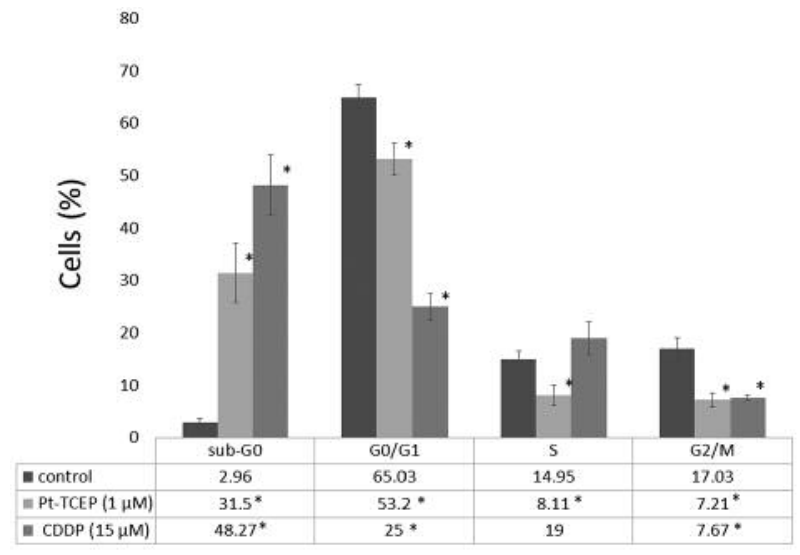

Figure 6. Effects of Pt-TCEP and CDDP on cell-cycle phase progression in GL-1 line. Values are expressed as means $\pm S D$ of three independent experiments. Asterisk indicates statistical significance compared to control $(p<0.05)$.

The effect of TCEP was also evaluated. It showed no inhibitory activity towards canine lymphoma (CLBL-1, CL1) and leukemia (GL-1) cell lines at the applied 
concentrations. Other studies also indicated that it was not only harmless to the cells but also that its reductive properties could protect cells from deleterious effects of reactive oxygen species (ROS). In a rat optic nerve crush model of axotomy TCEP was found to be neuroprotective in in vivo model of retinal ganglion cell (RGC) axonal damage (37). In vitro studies of RGC survival under reduced conditions showed that incubation of the retinal ganglion cells with TCEP resulted in a long-term survival equivalent to or better than the incubation with neurotrophic factors (38). However, higher concentration of the agent was used to achieve this $(100 \mu \mathrm{M})$, and at lower concentrations TCEP did not show any neuroprotective activity $(37,38)$.

The study demonstrated the degree to which the cell death was related to apoptosis, the main mechanism by which DNA-binding anticancer drugs, such as platinum based drugs, cause death of cancer cells (39). We showed that similar concentrations of Pt-TCEP were responsible for the inhibition of cell viability and apoptosis. As demonstrated in cell viability assay, at $1 \mu \mathrm{M}$ Pt-TCEP cell viability in GL-1 cell line were reduced to approximately $70 \%$, while the apoptosis rate was $31.25 \pm 1.16 \%$. CLBL-1 viability was inhibited by ca. $50 \%$, and the percentage of apoptotic cells was $65.53 \pm 2.89 \%$ at this concentration. In CL-1 cell line, the inhibition of viability was not detected, while the apoptosis rate was estimated to be $12.35 \pm 0.44 \%$. These results showed that the cells exposing phosphatidylserine on the outer leaflet of the membrane also lost their membrane integrity and apoptosis was responsible for cytotoxicity of Pt-TCEP. Apoptosis rate for CDDP was similar in all cell lines and amounted to $37.80 \pm 3.9 \%$ for GL-1, $45.67 \pm 5.58 \%$ for CLBL1 , and $37.80 \pm 5.76 \%$ for CL-1. Although apoptosis rate in CL-1 cell line at $15 \mu \mathrm{M}$ CDDP was similar to that in GL-1 and CLBL-1 cell lines, and in Pt-TCEP variant the percentage of apoptotic cells was much lower than in the other cell lines, further investigation revealed that at higher concentrations of CDDP the percentage of apoptotic cells did not increase and matched the results for cell viability assay in this cell line. Nevertheless, apoptotic events caused by PtTCEP were detected at the concentration 15-times lower than in the case of CDDP.

The most common cell cycle perturbations caused by cisplatin and other platinum-based drugs is a transient slowing of cell cycle progression in $\mathrm{S}$ phase and its arrest in $\mathrm{G}_{2} / \mathrm{M}$ phase (40-43). Cell cycle arrest in $\mathrm{G}_{2} / \mathrm{M}$ phase is required to repair the damage and prevent mitosis of damaged cells (44). The cells with cisplatin-damaged DNA slowdown in the transit through $\mathrm{S}$ phase and when they reach $\mathrm{G}_{2}$ phase they remain there for some time and, depending on the level of DNA damage, may return to the cycle and divide or undergo apoptosis $(40,45)$. However, the referenced studies were conducted at lower concentration of CDDP applied for only two hours and these observations were made during several days after the drug exposure (40, 41, 43, 45). With increasing dose of the drug and longer periods of exposure this influence could not be showed so clearly due to high concentration of cells in sub- $\mathrm{G}_{0}$ phase indicating that the cells might undergo apoptosis (46). Similar results were achieved in this study, where, due to high concentrations of CDDP used for a long period of time, the percentage of cells in sub- $\mathrm{G}_{0}$ phase significantly increased, and the percentage of cells in $\mathrm{G}_{0} / \mathrm{G}_{1}$ significantly decreased. A decrease in the percentage of $\mathrm{G}_{2} / \mathrm{M}$ cells was also observed but not in $\mathrm{S}$ phase, where the percentage of cells was not statistically different from the control. Nevertheless, the impact of PtTCEP on the cell cycle was different than that of CDDP. The increase in the percentage of the sub- $\mathrm{G}_{0}$ cells was smaller, and the decrease in the percentage of the $G_{0} / G_{1}$ cells was not evident. Contrary to cisplatin, Pt-TCEP reduced the number of cells in the $S$ phase, while in the $G_{2} / M$ phase the effect of both compounds was similar. This may indicate that PtTCEP did not arrest the cell cycle in the $\mathrm{S}$ phase before inducing apoptosis and that the mechanism involved in cell death triggered by the studied compound was not similar to that of CDDP, but further studies at various Pt-TCEP concentrations and exposure times are needed to confirm this.

This study clearly showed that Pt-TCEP was more potent in inducing cell death than CDDP in canine cancer cell lines. However, further investigations are needed to elucidate its biological activity.

\section{Acknowledgements}

The Authors wish to thank B.C. Ruetgen (Institute of Immunology, Department of Pathobiology, University of Veterinary Medicine in Vienna) for providing CLBL-1 cell line, and Y. Fujino and H. Tsujimoto (University of Tokyo, Department of Veterinary Internal Medicine) for providing the CL-1 and GL-1 cell lines. Publication was supported by Wroclaw Centre of Biotechnology, programme: the Leading National Research Centre (KNOW) for the years 20142018. The Authors declare no conflict of interest.

\section{References}

1 Dilruba S and Kalayda GV: Platinum-based drugs: past, present and future. Cancer Chemother Pharmacol 77: 1103-1124, 2016.

2 Kelland L: The resurgence of platinum-based cancer chemotherapy. Nat Rev Cancer 7: 573-584, 2007.

3 Lebwohl D and Canetta R: Clinical development of platinum complexes in cancer therapy: an historical perspective and an update. Eur J Cancer 34: 1522-1534, 1998.

4 Wheate NJ, Walker S, Craig GE and Oun R: The status of platinum anticancer drugs in the clinic and in clinical trials. Dalton Trans 39: 8113-8127, 2010.

5 Barabas K, Milner R, Lurie D and Adin C: Cisplatin: a review of toxicities and therapeutic applications. Vet Comp Oncol 6: 1$18,2008$. 
6 Shapiro W, Kitchell BE, Fossum TW, Couto CG and Theilen G: Cisplatin for treatment of transitional cell and squamous cell carcinomas in dogs. J Am Vet Med Assoc 193: 1530-1533, 1988.

7 Kraegel SA, Madewell BR, Simonson E and Gregory CR: Osteogenic sarcoma and cisplatin chemotherapy in dogs: 16 cases (1986-1989). J Am Vet Med Assoc 199: 1057-1059, 1991.

8 Straw RC, Withrow SJ, Richter SL, Powers BE, Klein MK, Postorino NC, LaRue SM, Ogilvie GK, Vail DM and Morrison WB: Amputation and cisplatin for treatment of canine osteosarcoma. J Vet Intern Med Am Coll Vet Intern Med 5: 205 210, 1991.

9 Thompson JP and Fugent MJ: Evaluation of survival times after limb amputation, with and without subsequent administration of cisplatin, for treatment of appendicular osteosarcoma in dogs: 30 cases (1979-1990). J Am Vet Med Assoc 200: 531-533, 1992.

10 Freeman KP, Hahn KA, Harris FD and King GK: Treatment of dogs with oral melanoma by hypofractionated radiation therapy and platinum-based chemotherapy (1987-1997). J Vet Intern Med Am Coll Vet Intern Med 17: 96-101, 2003.

11 Théon AP, Pascoe JR, Carlson GP and Krag DN: Intratumoral chemotherapy with cisplatin in oily emulsion in horses. J Am Vet Med Assoc 202: 261-267, 1993.

12 Théon AP, Pascoe JR, Madigan JE, Carlson G and Metzger L: Comparison of intratumoral administration of cisplatin versus bleomycin for treatment of periocular squamous cell carcinomas in horses. Am J Vet Res 58: 431-436, 1997.

13 Rabik CA and Dolan ME: Molecular mechanisms of resistance and toxicity associated with platinating agents. Cancer Treat Rev 33: 9-23, 2007

14 Siddik ZH: Cisplatin: mode of cytotoxic action and molecular basis of resistance. Oncogene 22: 7265-7279, 2003.

15 Bruijnincx PCA and Sadler PJ: New trends for metal complexes with anticancer activity. Curr Opin Chem Biol 12: 197-206, 2008.

16 Pruchnik H, Lis $\mathrm{T}$ and Pruchnik FP: Platinum(II) complexes with tris(2-carboxyethyl)phosphine, X-ray structure and reactions with polar solvents and glutathione. J Organomet Chem 791: 124-129, 2015.

17 Burns JA, Butler JC, Moran J and Whitesides GM: Selective reduction of disulfides by tris(2-carboxyethyl)phosphine. J Org Chem 56: 2648-2650, 1991.

18 Getz EB, Xiao M, Chakrabarty T, Cooke R and Selvin PR: A comparison between the sulfhydryl reductants tris(2carboxyethyl)phosphine and dithiothreitol for use in protein biochemistry. Anal Biochem 273: 73-80, 1999.

19 Liu P, O’Mara BW, Warrack BM, Wu W, Huang Y, Zhang Y, Zhao R, Lin M, Ackerman MS, Hocknell PK, Chen G, Tao L, Rieble S, Wang J, Wang-Iverson DB, Tymiak AA, Grace MJ and Russell RJ: A tris (2-carboxyethyl) phosphine (TCEP) related cleavage on cysteine-containing proteins. J Am Soc Mass Spectrom 21: 837-844, 2010.

20 Chen S, Jiang H, Wei K and Liu Y: Tris-(2-carboxyethyl) phosphine significantly promotes the reaction of cisplatin with Sp1 zinc finger protein. Chem Commun 49: 1226, 2013.

21 Safe S and Abdelrahim M: Sp transcription factor family and its role in cancer. Eur J Cancer 41: 2438-2448, 2005.

22 Sankpal UT, Goodison S, Abdelrahim M and Basha R: Targeting $\mathrm{Sp} 1$ transcription factors in prostate cancer therapy. Med Chem Shāriqah United Arab Emir 7: 518-525, 2011.
23 Rütgen BC, Hammer SE, Gerner W, Christian M, de Arespacochaga AG, Willmann M, Kleiter M, Schwendenwein I and Saalmüller A: Establishment and characterization of a novel canine B-cell line derived from a spontaneously occurring diffuse large cell lymphoma. Leuk Res 34: 932-938, 2010.

24 Nakaichi M, Taura Y, Kanki M, Mamba K, Momoi Y, Tsujimoto $\mathrm{H}$ and Nakama S: Establishment and characterization of a new canine B-cell leukemia cell line. J Vet Med Sci Jpn Soc Vet Sci 58: 469-471, 1996.

25 Momoi Y, Okai Y, Watari T, Goitsuka R, Tsujimoto H and Hasegawa A: Establishment and characterization of a canine Tlymphoblastoid cell line derived from malignant lymphoma. Vet Immunol Immunopathol 59: 11-20, 1997.

26 Kostova I: Platinum complexes as anticancer agents. Recent Patents Anticancer Drug Discov 1: 1-22, 2006.

27 Frezza M, Dou QP, Xiao Y, Samouei H, Rashidi M, Samari F and Hemmateenejad B: In vitro and in vivo antitumor activities and DNA binding mode of five coordinated cyclometalated organoplatinum(II) complexes containing biphosphine ligands. J Med Chem 54: 6166-6176, 2011.

28 Shi J-C, Yueng C-H, Wu D-X, Liu Q-T and Kang B-S: Chiral Phosphine Ligands Derived from Sugars. 16. Design and synthesis of platinum anticancer compounds with carbohydrate ligand. Organometallics 18: 3796-3801, 1999.

29 Samouei H, Rashidi M and Heinemann FW: A cyclometalated diplatinum complex containing 1,1'-bis(diphenylphosphino) ferrocene as spacer ligand: Antitumor study. J Organomet Chem 696: 3764-3771, 2011.

30 Ramos-Lima FJ, Quiroga AG, Pérez JM, Font-Bardía M, Solans $\mathrm{X}$ and Navarro-Ranninger C: Synthesis and characterization of new transplatinum complexes containing phosphane groups cytotoxic studies in cisplatin-resistant cells. Eur J Inorg Chem 2003: 1591-1598, 2003.

31 Quiroga AG, Ramos-Lima FJ, Alvarez-Valdés A, Font-Bardía M, Bergamo A, Sava G and Navarro-Ranninger C: Synthesis, characterization and tumor cell growth inhibition of new trans platinum complexes with phosphane derivatives. Polyhedron 30 : 1646-1650, 2011.

32 Eiter LC, Hall NW, Day CS, Saluta G, Kucera GL and Bierbach $\mathrm{U}$ : Gold(I) analogues of a platinum-acridine antitumor agent are only moderately cytotoxic but show potent activity against Mycobacterium tuberculosis. J Med Chem 52: 6519-6522, 2009.

33 Bagowski CP, You Y, Scheffler H, Vlecken DH, Schmitz DJ and Ott I: Naphthalimide gold(I) phosphine complexes as anticancer metallodrugs. Dalton Trans 2009: 10799-10805, 2009.

34 Schuh E, Valiahdi SM, Jakupec MA, Keppler BK, Chiba P and Mohr F: Synthesis and biological studies of some gold(I) complexes containing functionalised alkynes. Dalton Trans 2009: 10841-10845, 2009.

35 Pruchnik H, Lis T, Latocha M, Zielińska A and Pruchnik FP: Palladium(II) complexes with tris(2-carboxyethyl)phosphine, structure, reactions and cytostatic activity. J Inorg Biochem 156: 14-21, 2016.

36 Pawlak A, Rapak A, Zbyryt I and Obmińska-Mrukowicz B: The effect of common antineoplastic agents on induction of apoptosis in canine lymphoma and leukemia cell lines. In Vivo 28: 843$850,2014$.

37 Swanson KI, Schlieve CR, Lieven CJ and Levin LA: Neuroprotective effect of sulfhydryl reduction in a rat optic nerve crush model. Invest Ophthalmol Vis Sci 46: 3737-3741, 2005. 
38 Geiger LK, Kortuem KR, Alexejun C and Levin LA: Reduced redox state allows prolonged survival of axotomized neonatal retinal ganglion cells. Neuroscience 109: 635-642, 2002.

39 Gonzalez VM, Fuertes MA, Alonso C and Perez JM: Is cisplatin-induced cell death always produced by apoptosis? Mol Pharmacol 59: 657-663, 2001.

40 Sorenson CM and Eastman A: Mechanism of cis-diamminedichloroplatinum(II)-induced cytotoxicity: role of $\mathrm{G}_{2}$ arrest and DNA double-strand breaks. Cancer Res 48: 4484-4488, 1988.

41 Demarcq C, Bunch RT, Creswell D and Eastman A: The role of cell cycle progression in cisplatin-induced apoptosis in Chinese hamster ovary cells. Cell Growth Differ Mol Biol J Am Assoc Cancer Res 5: 983-993, 1994.

42 Nguyen HN, Sevin BU, Averette HE, Perras J, Ramos R, Donato $\mathrm{D}$, Ochiai $\mathrm{K}$ and Penalver $\mathrm{M}$ : Cell cycle perturbations of platinum derivatives on two ovarian cancer cell lines. Cancer Invest 11: 264-275, 1993.

43 Ormerod MG, Orr RM and Peacock JH: The role of apoptosis in cell killing by cisplatin: a flow cytometric study. Br J Cancer 69: 93-100, 1994.
44 Shapiro GI and Harper JW: Anticancer drug targets: cell cycle and checkpoint control. J Clin Invest 104: 1645-1653, 1999.

45 Sorenson $\mathrm{CM}$ and Eastman A: Influence of cis-diamminedichloroplatinum(II) on DNA synthesis and cell cycle progression in excision repair proficient and deficient Chinese hamster ovary cells. Cancer Res 48: 6703-6707, 1988.

46 Velma V, Dasari SR and Tchounwou PB: Low Doses of Cisplatin Induce Gene Alterations, Cell Cycle Arrest, and Apoptosis in Human Promyelocytic Leukemia Cells. Biomark Insights 11: 113-121, 2016
Received November 9, 2016

Revised December 21, 2016

Accepted December 28, 2016 